http:/www.journals.zu.edu.eg/journalDisplay.aspx?Journalld=1\&queryType=Master

\title{
EFFECT OF FOLIAR SPRAY WITH LITHOVIT ON DRY WEIGHT PRODUCTIVITY AND STORABILITY OF TWO GARLIC CULTIVARS
}

\author{
Amen M. Merwad", M.H. El-Sawah and A.A.M. Mohsen \\ Hort. Dept., Fac. Agric., Zagazig Univ., Egypt \\ Received: 01/08/2018 ; Accepted:26/09/2018
}

\begin{abstract}
A field experiment was carried out during the two successive winter seasons of 2015 /2016 and 2016/2017 in a Vegetative Private Farm at Hehia Distract, Sharkia Governorate, Egypt, to study the effect of lithovit as foliar application on dry weight, productivity and storability of two garlic cultivars (Balady and Sides 40). The obtained results were as follows: the interaction between Balady cultivar and spraying with lithovit at $5 \mathrm{~g} / \mathrm{l}$, increased dry weight of leaves, bulb and leaves + bulb dry weight/plant at 105 and 135 days after planting, and decreased fresh weight loss percentage in bulbs during storage period (180 days from storage) in both seasons. Also, the interaction between Balady cultivar and spraying with lithovit at $3 \mathrm{~g} / 1$, increased yield of grades 1, 2 and 3, exportable, marketable and total yield, as well as average bulb weight. On the other hand, Sides 40 cultivar without spraying with lithovit recorded the maximum values in yield of grade 4 in both seasons.
\end{abstract}

Key words: Garlic, lithovit, cultivars, foliar spray, dry weight, productivity, storability.

\section{INTRODUCTION}

Garlic (Allium sativum L.) as a member of the Alliaceae family is one of the most important vegetable bulb crops and is next to onion in importance. It is commonly used as a spice and many medicinal purposes. In Egypt, it has been generally cultivated for both local consumption and export. In addition, it is consumed as fresh and dried in the spice form, and as an ingredient to flavour the various dishes all over the world. In Egypt the total cultivated area of garlic, was about 29688 fad., during 2016 season which produced 280216 tons with average of 9.438 tons/faddan.

Nano-fertilizers are used recently as an alternative to conventional fertilizers for slow release and efficient use by plants. Nanofertilizers could enhance nutrient use efficiency and decrease the costs of environmental protection, (Naderi and Danesh Shahraki, 2013). Lithovet compound containing silica (5\%), magnesium carbonate $(4 \%)$ and calcium carbonate $(75 \%)$ particles, extremely small, which gives them the ability to enter through the

\footnotetext{
* Corresponding author: Tel. :+201098893436

E-mail address: abdo.soil@yahoo.com
}

stomata in leaves of plants when applied as foliar spray (Raven, 2003).

Increasing lithavit rates from zero (untreated) to the highest rate significantly increased plant gridgeth, yield and its components as well as pod and seed quality (Nassef and Nabeel, 2012 on broccoli; Byan, 2014 on bean; Farouk, 2015 on potato; Abdelghafar et al., 2016 on onion; Abo-Sedera et al., 2016 on snap bean; Hamoda et al., 2016 on cotton; Abdel Nabi et al., 2017 on lettuce; Abo El-Hamd and Abd Elwahed, 2018 on okra).

The present work aimed to study the effect of lithovit as foliar spraying on gridgeth, yield and storability of some garlic cultivars (Balady and Sides 40 ) gridgen under clay loam soil conditions.

\section{MATERIALS AND METHODS}

A field experiment was carried out during the two successive winter seasons of $2015 / 2016$ and 2016/2017 in a Vegetative Private Farm at Hehia Distract, Sharkia Governorate, Egypt, to 
study the effect of lithovit treatments (as foliar application) on dry weight, productivity and storability of some garlic cultivars (Balady and Sides 40). Physical and chemical properties of soil during 2015/2016 and 2016/2017 seasons (average two seasons) are shown in Table A.

This experiment was included (8) treatments, which were the combinations between the two garlic cultivars viz, Balady and Sides 40 and four rates of lithovit compound as foliar spray $(0,1,3$ and $5 \mathrm{~g} / \mathrm{l})$.

These treatments were distributed in a split plot design with three replicates, cultivars were randomly arranged in the main plots, while the rates of lithovit were randomly arranged in the sub-plots of the experiment.

The Lithovit was obtained from Agrolink Company as a powder, and chemical analysis of Lithovit were shown in Table B.

The experimental unit area was $12.6 \mathrm{~m}^{2}$. It contained three ridges with $7 \mathrm{~m}$ length and 60 $\mathrm{cm}$ in width. One ridge was used for the samples to measure the vegetative gridgeth characters and the other two ridges were used for yield determination.

Garlic cloves were selected for uniformity in shape and size. The cloves were sown at distance of $10 \mathrm{~cm}$ apart in the two sides of the ridge. Sowing was done on the first week of October in both gridgeing seasons of the study.

The plants were sprayed with lithovit three times at 60,75 and 90 days after planting in both seasons.

All plots were received equal amounts of the recommended dose of mineral $\mathrm{N}, \mathrm{P}$ and $\mathrm{K}$ fertilizers as $(90,60$ and $72 \mathrm{~kg} /$ fad.), respectively in the form of ammonium sulphate (20.6 N\%), calcium super phosphate $\left(15.5 \% \quad \mathrm{P}_{2} \mathrm{O}_{5}\right)$ and potassium sulphate $\left(48 \% \mathrm{~K}_{2} \mathrm{O}\right)$, respectively.

The normal agricultural practices in both experiments were carried out as commonly followed in district under flood irrigation system.

\section{Data Recorded}

\section{Dry weight}

Two samples each of ten plants were randomly taken from each plot at 105 and 135 days after planting in both seasons of the study to measure the dry weight of garlic plants expressed as follows:

\section{Dry weight}

1. Leaves dry weight /plant (g).

2. Bulb dry weight /plant (g).

3. Leaves + bulb dry weight/plant (g).

\section{Yield and its components}

At proper maturity stage of bulbs (about 200 days after planting), bulbs in every plot were harvested, then translocated to a shady place on the same day for curing. Plants were placed (about two weeks) in the shady place at $25 \pm$ $5^{\circ} \mathrm{C}$ and $60-75 \%$ relative humidity, and then graded into four categories according to the Ministry of Economic for garlic exportation (1963) as follow:

Grade 1: Bulbs with diameter above $5.5 \mathrm{~cm}$

Grade 2: Bulbs with diameter between 4.5-5.5 cm

Grade 3: Bulbs with diameter between 3.5-4.4 cm

Grade 4: Bulbs with diameter less than $3.5 \mathrm{~cm}$

1. Exportable yield (grade 1+grade 2) ton/fad.

2. Marketable yield (grade 1+grade $2+$ grade 3 ) ton/fad.

3. Total yield was (grade $1+$ grade $2+$ grade $3+$ grade 4) ton/fad.

4. Average bulb fresh weight $(\mathrm{g})=$

$$
\frac{\text { Yield of bulbs /plot }}{\text { Total number of bulbs/plot }}
$$

\section{Storability}

At harvest time, the yield of each plot was translocated to a shady place for curing and placed two weeks, then tops were removed to obtain uniform bulbs. Samples of cured plants (4 $\mathrm{kg}$ from each plot) were put in plastic crates and stored under normal room temperature $\left(25 \pm 5^{\circ} \mathrm{C}\right)$ and relative humidity $(70-75 \%)$ conditions. In 
Table A. Physical and chemical properties of the soil during 2015/2016 and 2016/2017 (average of two seasons)

\begin{tabular}{|c|c|}
\hline Character & Value \\
\hline \multicolumn{2}{|l|}{ Soil particles distribution } \\
\hline Sand (\%) & 23.04 \\
\hline Silt (\%) & 36.05 \\
\hline Clay $(\%)$ & 40.91 \\
\hline Texture & Clay loam \\
\hline Field Capacity (FC) (\%) & 27.3 \\
\hline $\mathrm{CaCO}_{3}(\%)$ & 1.10 \\
\hline Organic matter (\%) & 1.15 \\
\hline $\mathbf{p H} *$ & 8.10 \\
\hline $\operatorname{EC}\left(\mathrm{dSm}^{-1}\right)^{* *}$ & 1.30 \\
\hline \multicolumn{2}{|c|}{ Soluble cations and anions $\left(\mathrm{meq} / 100 \mathrm{~g}^{-1}\right)$} \\
\hline $\mathbf{C a}^{++}$ & 2.80 \\
\hline $\mathbf{M g}^{++}$ & 1.70 \\
\hline $\mathrm{Na}^{+}$ & 2.15 \\
\hline $\mathbf{K}^{+}$ & 0.15 \\
\hline $\mathrm{CO}_{3}^{--}$ & 0.00 \\
\hline $\mathrm{HCO}_{3}^{-}$ & 0.80 \\
\hline $\mathrm{Cl}^{-}$ & 1.80 \\
\hline $\mathrm{SO}_{4}^{--}$ & 4.20 \\
\hline \multicolumn{2}{|c|}{ Available nutrients (mg/ $\mathrm{kg}^{-1}$ soil) } \\
\hline Available N & 80.9 \\
\hline Available P & 12.5 \\
\hline Available K & 187 \\
\hline
\end{tabular}

${ }^{*}$ Soil water suspension 1:2.5 ${ }^{* *}$ soil water extract 1:5

Table B. Chemical analysis of lithovit according to Hamoda et al. (2016)

\begin{tabular}{lccc}
\hline Component & Value (\%) & Component & Value (\%) \\
\hline $\mathbf{C a ~ C O}_{3}$ & 79.19 & $\mathrm{SO}_{4}$ & 0.33 \\
$\mathbf{N}$ & 0.06 & $\mathrm{Fe}$ & 1.31 \\
$\mathbf{P}_{2} \mathbf{O}_{5}$ & 0.01 & $\mathrm{Zn}$ & 0.005 \\
$\mathrm{~K}_{2} \mathbf{O}$ & 0.21 & $\mathrm{Cu}$ & 0.002 \\
$\mathbf{M g C O}_{3}$ & 4.62 & $\mathrm{Mn}$ & 0.014 \\
Selenium dioxide & 11.41 & $\mathrm{NaO}$ & 0.55 \\
\hline
\end{tabular}


both seasons the storage zero time was May $7^{\text {th }}$ and the end was November $7^{\text {th }}$ (six month period).

Average room temperature and relative humidity (RH\%) during storage months are presented in Table $\mathrm{C}$.

Data were monthly recorded in both seasons of study as follows:

\section{Fresh weight loss percentage (FWL\%)}

Bulbs of each treatment were weighed at 30 days intervals during six months of storage period and then the cumulative weight loss percentage were calculated.

Fresh weight loss $(\%)=$

Initial weight- weight of bulbs for each sampling date

Initial weight of bulbs

\section{Statistical Analysis}

Statistical analysis was conducted for all collected data. The analysis of variance was calculated according to Snedecor and Cochran (1980), and means separation were done according to LSD at 0.05 probability level.

\section{RESULTS AND DISCUSSION}

\section{Dry Weight}

\section{Effect of cultivars}

There were significant differences between the two studied cultivars regarding their different parts of garlic dry weight, i.e., dry weight of leaves, bulb and leaves + bulb dry weight/plant at 105 and 135 days after planting (DAP) in both seasons (Table 1).

Balady cultivar recorded maximum values of dry weight of leaves, bulbs and leaves + bulb dry weight/plant than Sides 40 cultivar at 105 and 135 DAP (days after planting) in both seasons.

The differences between garlic cultivars could be attributed to the genetic differences between cultivars. Differences between garlic cultivars were also observed by Zaki (1984), Youssef and Tony (2014), Hassan (2015) and Hassan et al. (2016). They concluded that there were a different characters between the cultivars of garlic.

\section{Effect of lithovit rates}

Results in Table 2 show the effect of lithovit rates on dry weight of different parts of garlic in the both seasons.

Spraying garlic plants with lithovit at $5 \mathrm{~g} / 1$ increased dry weight of leaves, bulbs and leaves + bulb dry weight/plant at 105 and 135 DAP in both seasons. On the other hand, there were no significant differences due to spraying lithovit at 3 and $5 \mathrm{~g} / \mathrm{l}$ in respect of dry weight of leaves and leaves + bulb dry weight/plant at 105 days after planting in the $1^{\text {st }}$ and $2^{\text {nd }}$ seasons, respectively.

The increase in plant gridgeth in response to lithovit may be due to, its role as a long term reservoir supplying plants with $\mathrm{CO}_{2}$ (Bilal, 2010); thus, it can enhance plant gridgeth and productivity, where elevated $\mathrm{CO}_{2}$ concentrations generally increased carbon assimilation, biomass and leaf area of plants (Maswada and Abd ElRahman, 2014). It is well known that lithovit particles remain as a thin layer on the surface of leaves and penetrate frequently when they get wet with dew at night. Lithovit also contains nano-Mg, where magnesium is an essential nutrient for plant gridgeth and plays an important role in many plant physiological processes, such as photosynthesis ( $\mathrm{Mg}$ is the central element of the chlorophyll molecule), sugar synthesis, starch translocation, control of nutrient uptake. It also works as an enzyme activator, a constituent of many enzymes and a carrier of phosphorus in the plant (Allison et al., 2001).

These results are in harmony with these reported by Farouk (2015) on potato, AboSedera et al. (2016) on snap bean, Abdel Nabi et al. (2017) on lettuce and Abo El-Hamd and Abd Elwahed (2018) on okra. They found that sprayed plants with lithovit gave the highest values of dry weight of these different plants than unsprayed plants.

\section{Effect of the interaction between cultivars and lithovit rates}

The interaction between cultivars and lithovit at different rates had significant effect on the dry weight of different parts of garlic at 105 and 135 DAP in both seasons (Tables 3 and 4). 
Table C. Average room temperature $\left({ }^{\circ} \mathrm{C}\right)$ and relative humidity $(\%)$ during storage months in the two seasons

\begin{tabular}{lcc}
\hline Month & Temperature $\left({ }^{\mathbf{0}} \mathbf{C}\right)$ & Relative humidity (\%) \\
\cline { 2 - 3 } & $\mathbf{2 0 1 6}$ & $\mathbf{2 0 1 7}$ \\
\hline May & 25.42 & 8814 \\
June & 27.09 & 88.85 \\
July & 28.41 & 87.45 \\
August & 30.19 & 87.21 \\
September & 28.22 & 89.14 \\
October & 25.14 & 84.25 \\
November & 25.14 & 85.47 \\
\hline
\end{tabular}

Table 1. Effect of cultivars on dry weight of different plant parts of garlic at 105 and 105 days from planting during $2015 / 2016$ and $2016 / 2017$ seasons

\begin{tabular}{lcccccc}
\hline Treatment & $\begin{array}{c}\text { Dry weight of } \\
\text { leaves/plant (g) }\end{array}$ & \multicolumn{7}{c}{$\begin{array}{c}\text { Dry weight of } \\
\text { bulb/plant (g) }\end{array}$} & \multicolumn{2}{c}{$\begin{array}{c}\text { Leaves + bulb dry } \\
\text { weight/plant (g) }\end{array}$} \\
\cline { 2 - 8 } & \multicolumn{7}{c}{ Days after planting } \\
\cline { 2 - 8 } & $\mathbf{1 0 5}$ & $\mathbf{1 3 5}$ & $\mathbf{1 0 5}$ & $\mathbf{1 3 5}$ & $\mathbf{1 0 5}$ & $\mathbf{1 3 5}$ \\
\hline Cultivar & & $\mathbf{2 0 1 5 / 2 0 1 6}$ season & & \\
Balady & 9.01 & 15.36 & 5.01 & 10.44 & 14.02 & 25.80 \\
Sides 40 & 7.62 & 12.11 & 2.95 & 9.61 & 10.58 & 21.81 \\
LSD (0.05) & 0.89 & 0.49 & 0.33 & 0.70 & 1.15 & 1.11 \\
& & & $\mathbf{2 0 1 6 / 2 0 1 7}$ & season & & \\
Balady & 9.21 & 16.51 & 5.46 & 11.00 & 14.67 & 27.51 \\
Sides 40 & 7.50 & 13.48 & 3.29 & 10.16 & 10.79 & 23.65 \\
LSD (0.05) & $\mathrm{NS}$ & 0.37 & 0.31 & 0.53 & 1.86 & 0.88 \\
\hline
\end{tabular}


Table 2. Effect of lithovit rates on dry weight of different plant parts of garlic at 105 and 135 days from planting during 2015/2016 and 2016/2017 seasons

\begin{tabular}{|c|c|c|c|c|c|c|}
\hline \multirow[t]{3}{*}{ Treatment } & \multicolumn{2}{|c|}{$\begin{array}{l}\text { Dry weight of } \\
\text { leaves/plant (g) }\end{array}$} & \multicolumn{2}{|c|}{$\begin{array}{l}\text { Dry weight of } \\
\text { bulb/plant (g) }\end{array}$} & \multicolumn{2}{|c|}{$\begin{array}{c}\text { Leaves + bulb dry } \\
\text { weight/plant (g) }\end{array}$} \\
\hline & \multicolumn{6}{|c|}{ Days after planting } \\
\hline & 105 & 135 & 105 & 135 & 105 & 135 \\
\hline Lithovit rates & \multicolumn{6}{|c|}{$2015 / 2016$ season } \\
\hline 0 (control) & 6.86 & 11.01 & 2.94 & 7.09 & 9.81 & 18.27 \\
\hline 1g/l & 7.67 & 12.65 & 3.39 & 9.15 & 11.07 & 21.80 \\
\hline 3g/l & 9.17 & 14.73 & 4.45 & 11.17 & 13.63 & 25.90 \\
\hline $5 \mathrm{~g} / \mathrm{l}$ & 9.55 & 16.56 & 5.14 & 12.69 & 14.69 & 29.25 \\
\hline \multirow[t]{2}{*}{ LSD (0.05) } & 0.57 & 0.35 & 0.12 & 0.60 & 0.63 & 0.70 \\
\hline & \multicolumn{6}{|c|}{$2016 / 2017$ season } \\
\hline 0 (control) & 6.94 & 12.92 & 3.21 & 7.53 & 10.15 & 20.45 \\
\hline 1g/l & 8.04 & 14.59 & 3.98 & 9.65 & 12.02 & 24.24 \\
\hline $3 g / 1$ & 9.22 & 15.79 & 4.89 & 11.69 & 14.11 & 27.48 \\
\hline $5 \mathrm{~g} / \mathrm{l}$ & 9.55 & 16.69 & 5.41 & 13.45 & 14.63 & 30.14 \\
\hline LSD (0.05) & 0.50 & 0.26 & 0.22 & 0.67 & 0.59 & 0.71 \\
\hline
\end{tabular}

Table 3. Effect of the interaction between cultivars and lithovit rates on dry weight of different plant parts of garlic at 105 and 135 days from planting during 2015/2016 season

\begin{tabular}{lccccccc}
\hline Treatment & & $\begin{array}{c}\text { Dry weight of } \\
\text { leaves/plant (g) }\end{array}$ & \multicolumn{2}{c}{$\begin{array}{c}\text { Dry weight of } \\
\text { bulb/plant (g) }\end{array}$} & $\begin{array}{c}\text { Leaves + bulb dry } \\
\text { weight/plant (g) }\end{array}$ \\
\cline { 3 - 8 } & & \multicolumn{5}{c}{ Days after } & planting \\
\hline Cultivar & Lithovit & $\mathbf{1 0 5}$ & $\mathbf{1 3 5}$ & $\mathbf{1 0 5}$ & $\mathbf{1 3 5}$ & $\mathbf{1 0 5}$ & $\mathbf{1 3 5}$ \\
\hline Balady & $\mathbf{0 ~ ( c o n t r o l ) ~}$ & 7.62 & 12.02 & 3.67 & 8.09 & 11.30 & 20.11 \\
& $\mathbf{1}$ g/l & 8.43 & 14.32 & 4.27 & 9.25 & 12.70 & 23.57 \\
& $\mathbf{3 ~ g / l}$ & 9.89 & 17.08 & 5.96 & 11.13 & 15.85 & 28.21 \\
& $\mathbf{5}$ g/l & 10.09 & 18.02 & 6.14 & 13.30 & 16.23 & 31.32 \\
Sides 40 & $\mathbf{0 ( c o n t r o l )}$ & 6.10 & 10.00 & 2.22 & 6.09 & 8.32 & 16.42 \\
& $\mathbf{1}$ g/l & 6.92 & 10.99 & 2.51 & 9.05 & 9.43 & 20.04 \\
& $\mathbf{3 ~ g / l}$ & 8.46 & 12.38 & 2.95 & 11.21 & 11.42 & 23.59 \\
& $\mathbf{5}$ g/l & 9.02 & 15.10 & 4.13 & 12.08 & 13.15 & 27.18 \\
LSD (0.05) & & 0.80 & 0.50 & 0.17 & 085 & 0.90 & 0.90 \\
\hline
\end{tabular}


Table 4. Effect of the interaction between cultivars and lithovit rates on dry weight of different parts of garlic at 105 and 135 days from planting during 2016/2017 season

\begin{tabular}{|c|c|c|c|c|c|c|c|}
\hline \multirow[t]{2}{*}{ Treatment } & \multirow[b]{3}{*}{ Lithovit } & \multicolumn{2}{|c|}{$\begin{array}{l}\text { Dry weight of } \\
\text { leaves/plant (g) }\end{array}$} & \multicolumn{2}{|c|}{$\begin{array}{l}\text { Dry weight of } \\
\text { bulb/plant (g) }\end{array}$} & \multicolumn{2}{|c|}{$\begin{array}{c}\text { Leaves + bulb dry } \\
\text { weight/plant (g) }\end{array}$} \\
\hline & & \multicolumn{6}{|c|}{ Days after planting } \\
\hline Cultivar & & 105 & 135 & 105 & 135 & 105 & 135 \\
\hline \multirow[t]{4}{*}{ Balady } & 0 (control) & 7.75 & 14.24 & 4.03 & 8.44 & 11.78 & 22.68 \\
\hline & $1 \mathrm{~g} / \mathrm{l}$ & 9.18 & 16.42 & 5.07 & 9.97 & 14.25 & 26.38 \\
\hline & $3 \mathrm{~g} / \mathrm{l}$ & 9.92 & 17.12 & 6.10 & 11.82 & 16.02 & 28.94 \\
\hline & $5 \mathrm{~g} / \mathrm{l}$ & 10.00 & 18.26 & 6.64 & 13.77 & 16.64 & 32.03 \\
\hline \multirow[t]{4}{*}{ Sides 40} & 0 (control) & 6.13 & 11.60 & 2.40 & 6.63 & 8.53 & 18.23 \\
\hline & $1 \mathrm{~g} / \mathrm{l}$ & 6.90 & 12.76 & 2.90 & 9.33 & 9.80 & 22.09 \\
\hline & $3 \mathrm{~g} / \mathbf{1}$ & 8.52 & 14.46 & 3.68 & 11.56 & 12.20 & 26.02 \\
\hline & $5 \mathrm{~g} / 1$ & 8.45 & 15.12 & 4.18 & 13.13 & 12.63 & 28.25 \\
\hline LSD ( 0.05$)$ & & 0.70 & 0.37 & 0.31 & 0.95 & 0.84 & 1.00 \\
\hline
\end{tabular}

The interaction between Balady cultivar and spraying with lithovit at $5 \mathrm{~g} / 1$ increased the dry weight of leaves, bulb and total dry weight of whole plant at 105 and 135 DAP in both seasons in most casses, followed by the interaction between Balady cultivar and lithovit at $3 \mathrm{~g} / \mathrm{l}$.

\section{Yield and its Components}

\section{Effect of cultivars}

Results in Table 5 indicate that Balady cultivar gave the high values of yield of grades 1,2 and 3 , exportable, marketable and total yield, as well as average bulb weight, except, yield of grade 1 in the $1^{\text {st }}$ season, whereas Sides 40 cultivar increased yield of grade 4 .

These results are in agreement with those reported by Fattahallah et al. (1992), Osman et al. (1996), Abdalla et al. (2011), Mohsen (2012), Abdel-Razzak and El-Sharkawy, (2013) and Abo El-Fadel and Mohamed (2013) who found that the Balady garlic cultivar gave higher total yield and its components of bulbs, than other cultivars.

\section{Effect of lithovit rates}

The obtained results in Table 6 indicate that spraying garlic plants with lithovit at $5 \mathrm{~g} / \mathrm{l}$, increased yield of grades 1, 2 and 3, exportable, marketable and total yield, as well as average bulb weight, with no significant differences with lithovit at $3 \mathrm{~g} / \mathrm{l}$ as respect to yield of grade 1 and 2 in both seasons and exportable, marketable and total yield, as well as average bulb weight in the $1^{\text {st }}$ season. The control treatment (unsprayed plants) recorded the highest yield of grad 4 in this respect.

Lithovit contains nano-Iron which is one of the essential elements for plant gridgeth and plays an important role in the photosynthetic reactions. Iron activates several enzymes and contributes to RNA synthesis and improves the performance of photosystems, and then increased plant gridgeth and total yield (Zaki, 1984; Malakouti and Tehrani, 2005; Abou El-Magd et al., 2014; Youssef and Tony, 2014; Hassan, 2015; Hassan et al., 2016).

Similar findings were also obtained by Byan (2014) on snap bean, Farouk (2015) on potato and Abo El-Hamd and Abd Elwahed (2018) on okra. They found that plants sprayed with lithovit at $0.75 \mathrm{~g} / 1$, recoded the maximum values of pod parameters, such as length, diameter and weight, as well as, yield and its components i.e., total yield, weight and number of pods/plant were increased compared to the unsprayed plants. 
Table 5. Effect of cultivars on yield and its components of garlic during 2015/2016 and 2016/ 2017 seasons

\begin{tabular}{|c|c|c|c|c|c|c|c|c|}
\hline \multirow[t]{2}{*}{ Treatment } & \multicolumn{7}{|c|}{ Yield and its components (ton/fad.) } & \multirow{2}{*}{$\begin{array}{l}\text { Average } \\
\text { bulb weight } \\
\text { (g) }\end{array}$} \\
\hline & Grade 1 & Grade 2 & Grade 3 & Grade 4 & $\begin{array}{c}\text { Exportable } \\
\text { yield }\end{array}$ & $\begin{array}{c}\text { Marketable } \\
\text { yield }\end{array}$ & $\begin{array}{l}\text { Total } \\
\text { yield }\end{array}$ & \\
\hline Cultivar & \multicolumn{8}{|c|}{$2015 / 2016$ season } \\
\hline Balady & 2.326 & 2.982 & 1.756 & 0.532 & 5.308 & 7.065 & 7.597 & 68.26 \\
\hline Sides 40 & 1.869 & 2.271 & 1.406 & 0.695 & 4.140 & 5.547 & 6.243 & 61.70 \\
\hline \multirow[t]{2}{*}{ LSD (0.05) } & NS & 0.195 & 0.158 & 0.017 & 0.594 & 0.751 & 0.757 & 1.59 \\
\hline & \multicolumn{8}{|c|}{ 2016/2017 season } \\
\hline Balady & 2.426 & 3.150 & 1.405 & 0.528 & 5.576 & 6.982 & 7.511 & 75.48 \\
\hline Sides 40 & 1.894 & 2.404 & 1.082 & 0.626 & 4.299 & 5.381 & 6.008 & 63.54 \\
\hline LSD (0.05) & 0.124 & 0.186 & 0.035 & 0.062 & 0.310 & 0.312 & 0.251 & 2.22 \\
\hline
\end{tabular}

Table 6. Effect of lithovit rates on yield and its components of garlic during 2015/2016 and 2016/ 2017 seasons

\begin{tabular}{|c|c|c|c|c|c|c|c|c|}
\hline \multirow[t]{2}{*}{ Treatment } & \multicolumn{7}{|c|}{ Yield and its components (ton/fad.) } & \multirow{2}{*}{$\begin{array}{l}\text { Average } \\
\text { ulb weight } \\
\text { (g) }\end{array}$} \\
\hline & Grade 1 & Grade 2 & Grade 3 & Grade 4 & $\begin{array}{l}\text { Exportable } \\
\text { yield }\end{array}$ & $\begin{array}{c}\text { Marketable } \\
\text { yield }\end{array}$ & $\begin{array}{l}\text { Total } \\
\text { yield }\end{array}$ & \\
\hline Lithovit rate & \multicolumn{8}{|c|}{$2015 / 2016$ season } \\
\hline 0 (control) & 1.679 & 1.983 & 1.075 & 0.968 & 3.662 & 4.737 & 5.706 & 57.24 \\
\hline 1g/l & 1.874 & 2.411 & 1.550 & 0.665 & 4.286 & 5.836 & 6.502 & 62.88 \\
\hline $3 g / \mathbf{l}$ & 2.385 & 3.010 & 1.774 & 0.457 & 5.395 & 7.169 & 7.627 & 68.69 \\
\hline $5 \mathrm{~g} / \mathbf{l}$ & 2.452 & 3.101 & 1.927 & 0.365 & 5.553 & 7.480 & 7.845 & 71.12 \\
\hline \multirow[t]{2}{*}{ LSD (0.05) } & 0.274 & 0.257 & 0.164 & 0.096 & 0.390 & 0.474 & 0.486 & 1.14 \\
\hline & \multicolumn{8}{|c|}{ 2016/2017 season } \\
\hline 0 (control) & 1.771 & 2.004 & 1.041 & 0.813 & 3.776 & 4.817 & 5.630 & 60.33 \\
\hline 1g/l & 1.961 & 2.441 & 1.244 & 0.596 & 4.402 & 5.647 & 6.243 & 66.90 \\
\hline $3 g / 1$ & 2.368 & 3.228 & 1.269 & 0.510 & 5.596 & 6.865 & 7.376 & 74.03 \\
\hline $5 \mathrm{~g} / \mathrm{l}$ & 2.541 & 3.435 & 1.421 & 0.391 & 5.976 & 7.397 & 7.788 & 76.78 \\
\hline LSD (0.05) & 0.088 & 0.133 & 0.036 & 0.044 & 0.222 & 0.246 & 0.254 & 1.64 \\
\hline
\end{tabular}




\section{Effect of interaction between cultivars and lithovit rates}

Results in Tables 7 and 8 show that the interaction between Balady cultivar and spraying plants with lithovit at $3 \mathrm{~g} / 1$ increased yield of grades 1, 2 and 3, exportable, marketable and total yield, as well as average bulb weight with no significant differences with the interaction between Balady cultivar and lithovit at $5 \mathrm{~g} / 1$ in both seasons. On the other hand, Sides 40 cultivar without spraying with lithovit recorded the maximum value of yield of grade 4 , in both seasons.

\section{Storability}

\section{Effect of cultivars}

Fresh weight loss percentage (FWL\%) in bulb increased with prolonging storage period up to 180 days of storage (Table 9). Balady cultivar recorded lower FWL(\%) during storage periods compared to Sides 40 cultivar.

The obtained results are in harmony with those reported by Ammar (2007), AbdelRazzak and El-Sharkawy (2013) and Hassan et al. (2016) on garlic. They found that Balady cultivar gave the lowest value of total weight loss (\%) at the end of storage under temperature room than Sids 40 cultivar.

\section{Effect of lithovit rates}

Fresh weight loss (\%) significantly decreased with increasing lithovit up to 3 or $5 \mathrm{~g} / 1$ during storage period up to 180 days (Table 10). This mean that lithovit at $5 \mathrm{~g} / 1$ recorded the lowest values of FWL (\%) in most period, in both seasons, whereas, the control treatment (unsprayed) recorded the highest value of FWL (\%) in bulbs.

\section{Effect of the interaction between cultivars and lithovit rates}

Results in Tables 11 and 12 illustrate that, in general, the interaction between Balady cultivar and spraying with lithovit at $5 \mathrm{~g} / \mathrm{l}$ gave the lowest values of FWL (\%) in bulbs during storage periods, whereas, the interaction between Sides 40 cultivars and control treatment (unsprayed) gave the highest values of FWL (\%) during storage periods.

Conclusively, it could be concluded that, the best interaction treatment for enhancing yield and storability were recorded by the interaction between Balady cultivar and sprayed garlic plants with lithovit at $5 \mathrm{~g} /$ liter under the same conditions of this study.

Table 7. Effect of the interaction between cultivars and lithovit rates on yield and its components of garlic during 2015/2016 season

\begin{tabular}{|c|c|c|c|c|c|c|c|c|c|}
\hline \multicolumn{2}{|c|}{ Treatment } & \multicolumn{7}{|c|}{ Yield and its components (ton/fad.) } & \multirow{2}{*}{$\begin{array}{c}\text { Average } \\
\text { bulb } \\
\text { weight (g) }\end{array}$} \\
\hline Cvs & $\begin{array}{l}\text { Lithovit } \\
\text { rates }\end{array}$ & Grade 1 & Grade 2 & Grade 3 & Grade 4 & $\begin{array}{c}\text { Exportable } \\
\text { yield }\end{array}$ & $\begin{array}{c}\text { Marketable } \\
\text { yield }\end{array}$ & $\begin{array}{l}\text { Total } \\
\text { yield }\end{array}$ & \\
\hline \multirow[t]{4}{*}{ Balady } & 0 (control) & 1.946 & 2.397 & 1.305 & 0.964 & 4.344 & 5.649 & 6.614 & 62.62 \\
\hline & $1 \mathrm{~g} / \mathbf{l}$ & 2.210 & 2.821 & 1.812 & 0.447 & 5.032 & 6.844 & 7.291 & 65.06 \\
\hline & $3 \mathrm{~g} / \mathrm{l}$ & 2.669 & 3.356 & 1.904 & 0.365 & 6.025 & 7.929 & 8.294 & 71.68 \\
\hline & $5 \mathrm{~g} / \mathrm{l}$ & 2.480 & 3.353 & 2.005 & 0.353 & 5.833 & 7.838 & 8.192 & 73.71 \\
\hline \multirow[t]{4}{*}{ Sides 40} & 0 (control) & 1.412 & 1.569 & 0.845 & 0.972 & 2.981 & 3.826 & 4.798 & 51.86 \\
\hline & $1 \mathrm{~g} / \mathbf{l}$ & 1.538 & 2.002 & 1.288 & 0.884 & 3.540 & 4.829 & 5.714 & 60.70 \\
\hline & $3 \mathrm{~g} / \mathrm{l}$ & 2.102 & 2.664 & 1.644 & 0.549 & 4.766 & 6.410 & 6.960 & 65.71 \\
\hline & $5 \mathrm{~g} / 1$ & 2.424 & 2.849 & 1.849 & 0.376 & 5.273 & 7.123 & 7.499 & 68.54 \\
\hline \multicolumn{2}{|c|}{ LSD (0.05) } & 0.387 & 0.364 & 0.232 & 0.137 & 0.551 & 0.670 & 0.686 & 1.61 \\
\hline
\end{tabular}


Table 8. Effect of the interaction between cultivars and lithovit rates on yield and its components of garlic during 2016/2017 season

\begin{tabular}{|c|c|c|c|c|c|c|c|c|c|}
\hline \multicolumn{2}{|l|}{ Treatment } & \multicolumn{7}{|c|}{ Yield and its components (ton/fad.) } & \multirow{2}{*}{$\begin{array}{c}\text { Average } \\
\text { bulb } \\
\text { weight (g) }\end{array}$} \\
\hline$\overline{\mathrm{Cvs}}$ & $\begin{array}{l}\text { Lithovit } \\
\text { rates }\end{array}$ & Grade 1 & Grade 2 & Grade 3 & Grade 4 & $\begin{array}{c}\text { Exportable } \\
\text { yield }\end{array}$ & $\begin{array}{c}\text { Marketable } \\
\text { yield }\end{array}$ & $\begin{array}{l}\text { Total } \\
\text { yield }\end{array}$ & \\
\hline \multirow[t]{4}{*}{ Balady } & 0 (control) & 1.980 & 2.470 & 1.185 & 0.786 & 4.450 & 6.555 & 6.421 & 68.80 \\
\hline & $1 \mathrm{~g} / \mathbf{l}$ & 2.139 & 2.980 & 1.436 & 0.467 & 5.119 & 6.836 & 7.022 & 75.24 \\
\hline & $3 \mathrm{~g} / \mathrm{l}$ & 2.757 & 3.620 & 1.404 & 0.440 & 6.377 & 7.781 & 8.221 & 78.09 \\
\hline & $5 \mathrm{~g} / \mathrm{l}$ & 2.830 & 3.530 & 1.598 & 0.422 & 6.360 & 7.958 & 8.380 & 79.79 \\
\hline \multirow[t]{4}{*}{ Sides 40} & 0 (control) & 1.563 & 1.539 & 0.898 & 0.840 & 3.102 & 4.000 & 4.840 & 51.86 \\
\hline & $1 \mathrm{~g} / \mathrm{l}$ & 1.784 & 1.902 & 1.053 & 0.726 & 3.686 & 4.739 & 5.465 & 58.56 \\
\hline & $3 \mathrm{~g} / \mathrm{l}$ & 1.980 & 2.836 & 1.134 & 0.581 & 4.816 & 5.635 & 6.531 & 69.98 \\
\hline & $5 \mathrm{~g} / \mathrm{l}$ & 2.252 & 3.340 & $1.244 \mathrm{c}$ & 0.360 & 5.592 & 5.950 & 7.196 & 73.77 \\
\hline LSD (0.05) & & 0.125 & 0.188 & 0.051 & 0.62 & 0.314 & 0.348 & 0.359 & 2.32 \\
\hline
\end{tabular}

Table 9. Effect of cultivars on fresh weight loss percentage of garlic bulbs during storage period in 2015/2016 and 2016/2017 seasons

\begin{tabular}{lcccccc}
\hline Treatment & \multicolumn{7}{c}{ Days after storage } \\
\cline { 2 - 7 } & $\mathbf{3 0}$ & $\mathbf{6 0}$ & $\mathbf{9 0}$ & $\mathbf{1 2 0}$ & $\mathbf{1 5 0}$ & $\mathbf{1 8 0}$ \\
\hline Cultivar & 4.09 & 7.86 & 10.73 & 13.92 & 18.24 & 20.46 \\
Balady & 8.58 & 11.08 & 13.21 & 19.97 & 22.02 & 25.52 \\
Sides 40 & 1.37 & 2.19 & 2.46 & 1.89 & 2.08 & 2.71 \\
LSD (0.05) & & & $\mathbf{2 0 1 6 / 2 0 1 7}$ & season & & \\
& 3.59 & 6.63 & 9.84 & 13.09 & 16.65 & 18.78 \\
Balady & 8.07 & 9.92 & 11.91 & 18.02 & 19.95 & 23.24 \\
Sides 40 & 1.79 & 1.46 & 1.42 & 2.14 & 1.89 & 2.01 \\
LSD (0.05) & & & & & & \\
\hline
\end{tabular}


Table 10. Effect of lithovit rates on fresh weight loss percentage of garlic bulbs during storage period in 2015/2016 and 2016/2017 seasons

\begin{tabular}{lcccccc}
\hline Treatment & \multicolumn{7}{c}{ Days after storage } \\
\cline { 2 - 7 } & $\mathbf{3 0}$ & $\mathbf{6 0}$ & $\mathbf{9 0}$ & $\mathbf{1 2 0}$ & $\mathbf{1 5 0}$ & $\mathbf{1 8 0}$ \\
\hline Lithovit rate & & & $\mathbf{2 0 1 5} / \mathbf{2 0 1 6}$ & season & & \\
$\mathbf{0}$ (control) & 7.45 & 9.86 & 13.53 & 18.55 & 21.63 & 25.61 \\
$\mathbf{1}$ g/l & 6.17 & 9.28 & 12.30 & 18.14 & 21.59 & 24.25 \\
$\mathbf{3}$ g/l & 5.63 & 9.17 & 11.06 & 15.93 & 18.06 & 20.46 \\
$\mathbf{5}$ g/l & 6.09 & 9.57 & 10.99 & 15.18 & 19.25 & 21.65 \\
$\mathbf{L S D}(\mathbf{0 . 0 5})$ & $\mathrm{NS}$ & $\mathrm{NS}$ & 1.83 & 1.61 & 1.27 & 1.88 \\
& & & $\mathbf{2 0 1 6 / 2 0 1 7}$ & $\mathbf{s e a s o n}$ & & \\
$\mathbf{0}$ (control) & 7.00 & 10.27 & 12.72 & 17.44 & 20.33 & 24.08 \\
$\mathbf{1}$ g/l & 5.80 & 9.23 & 11.56 & 16.55 & 19.80 & 22.79 \\
$\mathbf{3}$ g/l & 5.29 & 7.12 & 9.89 & 14.98 & 16.98 & 19.23 \\
$\mathbf{5}$ g/l & 5.23 & 6.50 & 9.33 & 13.27 & 16.10 & 17.95 \\
$\mathbf{L S D}(\mathbf{0 . 0 5})$ & 0.83 & 1.10 & 1.27 & 1.48 & 1.24 & 1.59 \\
\hline
\end{tabular}

Table 11. Effect of the interaction between cultivars and lithovit rates on fresh weight loss percentage of garlic bulbs during storage period in $2015 / 2016$ season

\begin{tabular}{lccccccc}
\hline Treatment & & \multicolumn{5}{c}{ Days after storage } \\
\cline { 3 - 8 } & & $\mathbf{3 0}$ & $\mathbf{6 0}$ & $\mathbf{9 0}$ & $\mathbf{1 2 0}$ & $\mathbf{1 5 0}$ & $\mathbf{1 8 0}$ \\
\hline Cvs & $\begin{array}{c}\text { Lithovit } \\
\text { rates }\end{array}$ & & & & & & \\
\hline Balady & $\mathbf{0}$ (control) & 5.36 & 7.13 & 12.24 & 15.18 & 19.50 & 22.50 \\
& $\mathbf{1}$ g/l & 3.36 & 6.33 & 10.36 & 14.80 & 18.97 & 21.54 \\
& $\mathbf{3}$ g/l & 3.28 & 8.81 & 10.76 & 13.46 & 16.79 & 18.83 \\
& $\mathbf{5}$ g/l & 4.34 & 9.15 & 9.55 & 12.25 & 17.71 & 18.97 \\
Sides 40 & $\mathbf{0}(\mathbf{c o n t r o l})$ & 9.53 & 12.58 & 14.81 & 21.91 & 23.75 & 28.72 \\
& $\mathbf{1 ~ g / l}$ & 8.98 & 12.23 & 14.23 & 21.47 & 24.21 & 26.95 \\
& $\mathbf{3}$ g/l & 7.98 & 9.52 & 11.35 & 18.40 & 19.33 & 22.08 \\
& $\mathbf{5}$ g/l & 7.84 & 9.99 & 12.43 & 18.10 & 20.79 & 24.32 \\
LSD (0.05) & & 1.49 & 2.36 & 2.59 & 2.28 & 1.79 & 2.66 \\
\hline
\end{tabular}


Table 12. Effect of the interaction between cultivars and lithovit rates on fresh weight loss percentage of garlic bulbs during storage period in 2016/2017 seasons

\begin{tabular}{|c|c|c|c|c|c|c|c|}
\hline \multirow[t]{2}{*}{ Treatment } & & \multicolumn{6}{|c|}{ Days after storage } \\
\hline & & 30 & 60 & 90 & 120 & 150 & 180 \\
\hline Cvs & $\begin{array}{c}\text { Lithovit } \\
\text { rates }\end{array}$ & & & & & & \\
\hline \multirow[t]{4}{*}{ Balady } & 0 (control) & 5.04 & 8.70 & 11.51 & 14.27 & 18.33 & 21.15 \\
\hline & $1 \mathrm{~g} / \mathbf{l}$ & 3.16 & 6.95 & 9.74 & 13.91 & 17.83 & 20.25 \\
\hline & $3 \mathrm{~g} / \mathrm{l}$ & 3.08 & 5.28 & 9.11 & 12.65 & 15.78 & 17.70 \\
\hline & $5 \mathrm{~g} / 1$ & 3.08 & 5.60 & 8.98 & 11.52 & 14.65 & 16.03 \\
\hline \multirow[t]{4}{*}{ Sides 40} & 0 (control) & 8.96 & 11.83 & 13.92 & 20.60 & 22.33 & 27.00 \\
\hline & $1 \mathrm{~g} / \mathrm{l}$ & 8.44 & 11.50 & 13.38 & 19.18 & 21.76 & 25.33 \\
\hline & $3 \mathrm{~g} / \mathrm{l}$ & 7.50 & 8.95 & 10.67 & 17.30 & 18.17 & 20.76 \\
\hline & $5 \mathrm{~g} / \mathrm{l}$ & 7.37 & 7.39 & 9.68 & 15.01 & 17.54 & 19.86 \\
\hline LSD (0.05) & & 1.17 & 1.56 & 1.79 & 2.09 & 1.76 & 2.25 \\
\hline
\end{tabular}

\section{REFERENCES}

Abdalla, M.A., M.H. Aboul-Nasr, A.K. Metwaly and H.A. Shreen (2011). Gridgeth and yield of fifteen garlic ecotypes. Assiut J. Agric. Sci., 36 (5): 52-65.

Abdel Nabi, H.M.A., K.K. Dawa, E.I. ElGamily and Y.F.E. Imryed (2017). Effect of magnetic water, foliar application with nano material and nitrogen levels on productivity and quality of head lettuce. Int. J. Adv. Res. Biol. Sci., 4 (5): 171-181.

Abdelghafar, M.S., M.T. Al-Abd, A.A. Helaly and A.M. Rashwan (2016). Foliar application of lithovit and rose water as factor for increasing onion seed production. Nat. and Sci., 14 (3): 53-61.

Abdel-Razzak, H.S. and G.A. El-Sharkawy (2013). Effect of biofertilizer and humic acid applications on gridgeth, yield, quality and storability of two garlic (Allium sativum L.) cultivars. Asian J. Crop Sci., 5: 48-64.

Abo El-Fadel, N.I. and W.H. Mohamed (2013). Response of two garlic cultivars to foliar nutrition under irrigation with saline water. Egypt. J. Soil Sci., 53 (2): 207-220
Abo El-Hamd, A.S.A. and A.H.M. Abd Elwahed (2018). Improving the gridgeth and yield of okra plants (Abelmoschus esculentus L.) using Lithovit fertilizer. Acad. J. Sci. Res., 6 (5): 65-71.

Abo-Sedera, F.A., A.S. Shams, M.H.M. Mohamed and A. H.M. Hamoda (2016). Effect of organic fertilizer and foliar spray with some safety compounds on gridgeth and productivity of snap bean. Ann. Agric. Sci., Moshtohor, 54 (1): 105 - 118.

Abou El-Magd, M.M., M.F. Zaki, S.A. Abo Sedera and T.T. El-Shorbagy (2014). Evaluation of five garlic (Allium sativum L.) cultivars under bio-chemical and mineral fertilization. Middle East J. Agric. Res., 3 (4): 926-935.

Allison, M.F., J.H. Fower and E.J. Allen (2001). Factors affecting the magnesium nutrition of potatoes (Solanum tuberosum L.). J. Agric. Sci. Cambridge, 137 : 397- 409.

Ammar, A. (2007). Some studies on improving garlic productively. M.Sc. Thesis, Fac. Agric, El- Mania Univ., Egypt.

Bilal, A.B. (2010). Recommended application of lithovit on different plants. Presented at the $3^{\text {rd }}$ Conf. Agric. Bio. Sci., (LeCAB 2010) 
Byan, U.A.I. (2014). Influence of using some safety materials on water requirement and water use efficiency of snap bean plant. Arab Univ. J. Agric. Sci., 22 (2): 381-393.

Farouk, S. (2015). Improving gridgeth and productivity of potato (Solanum tuberosum L.) by some biostimulants and lithovit with / or without boron. J. Plant Prod., Mansoura Univ., 6 (12): 2187 - 2206.

Fattahallah, M.A., F.A. Ali and R.A. Gawish (1992). Response of two garlic cultivars to planting distances and $\mathrm{K}$ levels of fertilization. (Yield and storability). Zagazig J. Agric. Res., Egypt, 19 (3): 1347-1360.

Hamoda, S.A.F., A.N.E. Attia, M.H. El-Hendi and S.O.S. El-Sayed (2016). Effect of nanofertilizer (Lithovit) and potassium on gridgeth,fruiting and yield of Egyptian cotton under different planting dates. Int. J. Adv. Res. Biol. Sci., 3:29-49.

Hassan, A.H. (2015). Improving gridgeth and productivity of two garlic cultivars (Allium sativum L.) Gridgen under sandy soil Conditions. Mid. East J. Agric. Res., 4 (2): 332-346.

Hassan, G.H., M.A. El-Shal, K.H.A. Soliman, and I.M. Ghoneim (2016). Effect of planting dates and periods of curing on quantitative, qualitative characteristics and storage ability of two garlic cultivars. J. Agric. Res. Kafr ElSheikh Univ., 42 (3): 401-414.

Malakouti, M. and M. Tehrani (2005). Micronutrient role in increasing yield and improving the quality of agricultural products. $1^{\text {st }}$ Ed. Tarbiat Modarres Press, Tehran.

Maswada, H.F. and L.A. Abd El-Rahman (2014). Inducing salinity tolerance in wheat plants by hydrogen peroxide and lithovit "A nano- $\mathrm{CaCO}_{3}$ fertilizer". J. Agric. Res. Kafr El-Sheikh Univ., 40 (4): 696-719.

Mohsen, A.A.M. (2012). Response of garlic plant to nitrogen, phosphorus, potassium and some biofertilizer levels under sandy soil conditions. Ph.D. Thesis, Fac. Agric. Zagazig Univ., Egypt.

Naderi, M.R. and A. Danesh Shahraki (2013). Nano fertilizers and their roles in sustainable agriculture. Int. J. Agric. Crop Sci., 19 : 2229-2232.

Nassef, D.M.T. and A.H.M. Nabeel (2012). Response of two broccoli cultivars to foliar application of Lithovit fertilizer under two planting methods. Assiut J. Agric. Sci., 43 : 27- 45 .

Osman, A.Z., M.F. Wahba and A.M. AbdelHamid (1996). Response of two garlic cvs. (Egyptian and Chinese) to different irrigation and nitrogen fertilizer levels. Mirs, J. Agric. Eng., Cairo Univ. Irr. Conf., 3-4 April 1996.

Raven, J.A. (2003). Cycling silicon. The role of accumulation in plants. New Phytologist, 158: 419-421.

Snedecor, G.W. and W.G. Cochran (1980). Statistical Methods ( $8^{\text {th }}$ Ed.), Iowa Stat. Univ. Press. USA.

Youssef, N.S. and H.S.H. Tony (2014). Influence of different planting date on the performance of new garlic genotypes gridgen under El-Minia Governorate conditions. Nat. and Sci., 12 (5): 112-119.

Zaki, M.I.M. (1984). Effect of some agriculture treatments on garlic plants. M.Sc. Thesis, Fac. Agric., Zagazig Univ., Egypt. 
تأثير الرش الورقي بالليثوفيت على الوزن الجاف، الإنتاجية والقدرة التخزينية لصنفين من الثوم

أمين محمد مرواد ـ محسن حسن السواح ـ أحمد عبد الله محمود محسن

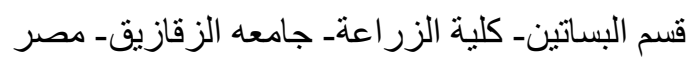

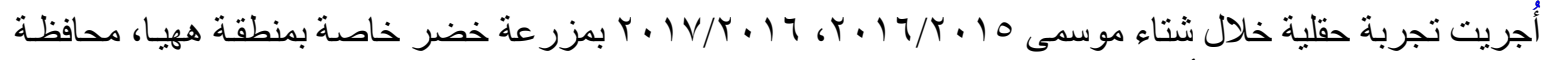

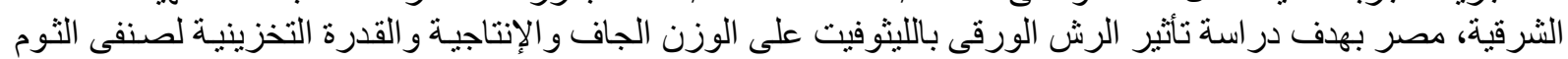

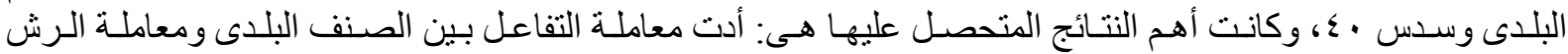

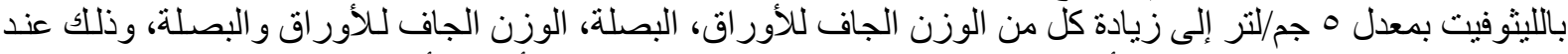

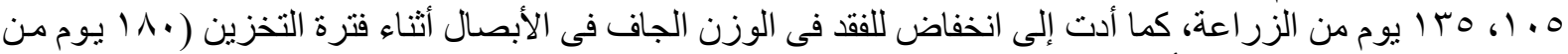

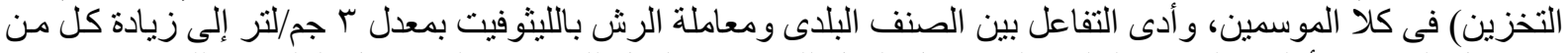

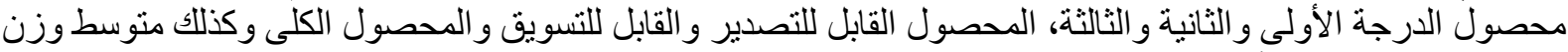

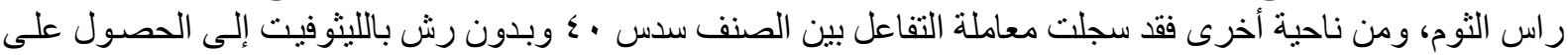
أعلى القيم لمحصول الومن الدرجة الر ابعة في كلا الموسمين. 